\title{
KONSTRUKSI SOSIAL PENDIDIKAN PESANTREN; ANALISIS PEMIKIRAN AZYUMARDI AZRA
}

\author{
Evi Fatimatur Rusydiyah \\ (UIN Sunan Ampel Surabaya)
}

\begin{abstract}
Abstrak:
Pesantren telah dianggap sebagai model institusi pendidikan yang memiliki keunggulan baik dari aspek tradisi keilmuan dan internalisasi moralitas umat Islam. Saat ini, pesantren terus berbenah dan mempersolek diri. Di sisi lain, banyak pihak mengadopsi unsur positif dalam diri pesantren. Pesantren menumbuhkan apresiasi yang sepatutnya terhadap semua perkembangan yang terjadi di masa kini dan mendatang. Proses mengambil dan memberi secara sosiologis dan antropologis ini merupakan konstruksi sosialnya. Penelitian kepustakaan ini bertujuan untuk mendekripsikan dinamika pendidikan Islam, khususnya menyorot konstruksi sosial pesantren dalam pandangan Azyumardi Azra. Hasil dari penelitian ini adalah bahwa pesantren sangat piawai berdialektika dengan tesis budaya yang saling bertentangan dan melahirkan sintesis konstruksi sosial baru. Pesantren juga merupakan institusi sosial yang paling kreatif dan inovatif Karena falsafahnya: al-muhafadhu 'alal qadimis sholeh wal akhdu bil jadidil ashlah (memelihara tradisi lama yang baik dan mengambil tradisi baru yang lebih baik). Hal ini juga menghadirkan nilai-nilai agama sebagai bobot atas sejumlah karya pendidikan, ekonomi dan budaya pesantren.
\end{abstract}

Kata Kunci: Konstruksi Sosial: Pendidikan Islam; Pesantren; Budaya; 


\begin{abstract}
:
Pesantren is considered as a model of educational institution with added value from scholarly tradition aspects and the internalization of Islamic morality. Contemporarily, pesantren keeps improving and maintaining its internal body. On the other hand, outsiders start to adopt existing positive values of pesantren. Pesantren grows relevant appreciation towards development today and in the future. The taking and giving process here is sociologically-anthropologically a social construct. This library research aims to describe the dynamics in Islamic education, particularly focusing on pesantren social construct within Azyumardi Azra's point of view. The result shows that pesantren is very adaptable towards "incompatible" culture to syntesize in new social constructs. Pesantren is also a type of creative and innovative social institution due to its philosophy: almuhafadhu 'alal qadimis shaleh wal akhdu bil jadidil ashlah (preserving good old tradition and adopting better new one). This results in the presence of religious values as the added values in various field such as education, economy, and pesantren culture.
\end{abstract}

\title{
Keywords: Social Construct; Islamic Education; Pesantren; Culture;
}

\section{A. Pendahuluan}

Ada dua pendapat mengenai awal berdirinya pondok pesantren di Indonesia. Pendapat pertama menyebutkan bahwa pondok pesantren berakar pada tradisi Islam sendiri dan pendapat kedua menyatakan bahwa sistem pendidikan model pondok pesantren adalah asli Indonesia. ${ }^{1}$ Model pendidikan pesantren yang berkembang di seluruh Indonesia mempunyai nama dan corak yang sangat bervariasi, di Jawa disebut pondok atau pesantren, di aceh di kenal rangkang dan di Sumatra Barat dikenal dengan nama Surau. Nama yang sekarang lazim diterima oleh umum adalah pondok pesantren.

Lahirnya pesantren bukan sekedar untuk memenuhi kebutuhan akan pentingnya pendidikan, tetapi juga untuk penyiaran agama Islam. Menurut $\mathrm{M}$. Dawam Raharjo, hal itu menjadi identitas pesantren pada awal pertumbuhannya, yaitu sebagai pusat penyebaran agama Islam, disamping sebagai sebuah lembaga pendidikan. ${ }^{2}$ Lebih dari itu, pesantren merupakan institusi sosial yang mengalami dialektika. Ini terjadi lantaran proses perubahan di dalam dan di luar pesantren. Awalnya, pesantren ditempatkan sebagai sub-kultur, sebagai agen community

1 DEPAG RI, Pondok Pesantren dan Madrasah Diniyah,Pertumbuhan dan Perkembangannya (Jakarta : Dirjen Kelembagaan Islam Indonesia, 2003) , 7.

2 M. Dawam Raharjo, Perkembangan Masyarakat dalam Perspektif Pesantren, Pengantar dalam M. Dawam Raharjo (ed), Pergaulan Dunia Pesantren : Membangun dari Bawah (Jakarta : P3M, 1985), VII.

Jurnal Pendidikan Agama Islam (Journal of Islamic Education Studies)

Volume 5 Nomor 1 (2017)

ISSN(p) 2089-1946\& ISSN(e) 2527-4511

Hal. 22 - 43 
development (pembangunan komunitas) desa dan masyarakat pinggiran, sebagai bagian dari sistem pendidikan nasional, sampai menjadi model pendidikan alternatif. Konteks sosiologis pesantren tersebut merupakan hasil dari proyeksi masyarakat pesantren sendiri, pemerintah dan masyarakat umum yang memerankankan pesantren dalam bidang pendidikan, sosial, budaya dan ekonomi.

Zaman telah memaksa pesantren melakukan perubahan internal. Di tengah atmosfir dunia pendidikan dan dunia ketenagakerjaan yang mengharuskan pendidikan formal dan tenaga kerja yang berijazah, maka banyak pesantren yang menyelenggarakan pendidikan formal tersebut, dan mencetak SDM pesantren yang berkompetensi di bidangnya masing-masing. Pada masamasa mendatang, agaknya peran pesantren amat besar. Misalnya, arus globalisasi dan industrialisasi telah menimbulkan depresi dan bimbanganya pemikiran serta suramnya prespektif masa depan maka pesantren amat dibutuhkan untuk menyeimbangakan akal dan hati. ${ }^{3}$ Dengan atmosfir seperti ini, perlahan tapi pasti mendorong lahirnya konstruksi sosial baru. Sementara, konstruksi sosial baru ini merupakan hasil interrelasi sosial antara pesantren dengan pesantaren, antara pesantren dengan dunia pendidikan dan antara pesantren dengan masyarakat umum.

Keberadaan sekolah-sekolah di dalam pesantren, mulai dari pendidikan dasar, pendidikan menengah sampai dengan pendidikan tinggi, merupakan sintetis dari tesis pesantren sebagai penyelenggara pendidikan agama, sekaligus antitesis pesantren bukan melulu penyelenggara pendidikan agama akan tetapi juga yang lain. Di samping ada MI, ada SD. Di samping ada MTs, ada SLTP. Disamping ada MA, ada SMU/SMK. Disamping ada STAI/IAI, ada akademi keperawatan, dan perguruan tinggi umum lainnya.

Sudah barang tentu, pengembangan kelembagaan pendidikan pesantren merupakan bukti empirik. Bahwa, pesantren adalah lembaga dinamis. Lembaga yang terus-menerus berkembang tanpa berhenti sedikit pun. Pembangunan fisik di beberapa pesantren malah tak ada hari tanpa aktifitas pembangunan, sedangkan secara kurikuler juga dikembangkan kualitas dan kuantitasnnya. Pesantren sekarang diakui kelebihan dan keunggulannya sebagai alternatif pendidikan yang menyatu-padukan anasir pendidikan secara holistik dan komprehensif, baik aspek kognitif, afektif maupun psikomotorik.

Pesantren telah dianggap sebagai model institusi pendidikan yang memiliki keunggulan baik dari aspek tradisi keilmuannya yang merupakan salah satu tradisi agung maupun sisi transmisi dan internalisasi moralitas umat Islam.

3 Lihat Ahmad Tafsir, Ilmu Pendidikan dalam Prespektif Islam (Bandung : Remaja Rosdakarya, 2001), 192. 
Evi Fatimatur Rusydiyah

Pesantren telah menjadi semacam local genius.4 Pesantren, sebagai alternatif pendidikan baru di tengah-tengah kegagalan lembaga pendidikan lain dalam membina moral dan life skill (keterampilan hidup), mulai dilirik oleh banyak pihak. Bahkan diadopsi sebagai model pendidikan baru, seperti "pesantren perguruan tinggi", atau pengasramaan siswa taruna, dan lain sebagainya. Hal ini menunjukkan bahwa peran pesantren telah merambah ke segala bidang bahkan telah menjadi bagian dari sistem pendidikan nasional kita, maka sangat keliru sekali ketika ada anggapan peran pesantren sangat kecil dan rendah dalam menyukseskan program pembangunan nasional.

Kehadiran pesantren dikatakan unik karena dua alasan yakni pertama, pesantren hadir untuk merespon terhadap situasi dan kondisi suatu masyarakat yang dihadapkan pada runtuhnya sendi-sendi moral atau bisa disebut perubahan sosial. Kedua, didirikannya pesantren adalah untuk menyebar luaskan ajaran universalitas Islam ke seluruh pelosok nusantara. ${ }^{5}$

Pesantren saat ini terus berbenah dan mempersolek diri, dan sisi lain banyak pihak mengadopsi unsur positif dalam diri pesantren. Pesantren menumbuhkan apresiasi yang sepatutnya terhadap semua perkembangan yang terjadi di masa kini dan mendatang. ${ }^{6}$ Proses take and give secara sosiologis dan antropologis ini, sejatinya merupakan konstruksi sosial ala Peter Berger dan Thomas Luckman, sebagimana terurai berikut ini: Pertama, eksternalisasi, yaitu usaha pencurahan energi dan ekspresi diri seorang atau sekelompok orang ke dunia luar yang multidimensional. Eksternalisasi menimbulkan kesan dan pesan yang melahirkan identitas sendiri yang khas dan unik dibandingkan dengan yang lain. Pengembangan kelembagaan pendidikan pesantren merupakan usaha pencurahaan energi umat untuk memberikan pelayanan pendidikan yang terbaik bagi perbaikan kondisi umat dan bangsa yang masih carut marut.

Kedua, obyektifikasi, yaitu hasil dari usaha pencurahan energi dan ekspresi diri, baik berupa mental spiritual maupun berupa fisik material. Hasil obyektifikasi berwujud realitas subyektif dan realitas obyektif di luar manusia dan berlainan dengan manusia itu sendiri. Dalam kerangka antropologis, obyektifikasi tersebut melahirkan anasir-anasir budaya, antara lain: ideas, activities dan artifacts. Obyektifikasi pesantren menghasilkan seperangkat ide, aktivitas, dan artifak. Pesantren telah melahirkan sistem bahasa, pengetahuan,

${ }^{4}$ Malik Fajar, Visi Pembaruan Pendidikan Islam (Jakarta: Lembaga Pengembangan Pendidikan dan Penyusunan Naskah Indonesia /LP3NI;1998), 126.

${ }^{5}$ Said Aqil Siradj, Pesantren Masa Depan, Wacana Pemberdayaan dan Transformasi Pesantren (Bandung : Pustaka Hidayah, 1999), 202.

${ }^{6}$ Azyumardi Azra, Pendidikan Islam, Tradisi dan Modernisasi Menuju Melinium Baru (Jakarta : Logos Wacana Ilmu, 2000), 51. 
sosial, peralatan hidup dan teknologi, mata pencarian hidup, religi dan seni tersendiri yang khas dan unik. Sistem tersebut tentu berbeda dengan sistem dalam komunitas sosial yang lain. Yang paling ekstrim terletak pada pranata nilai dan norma agama Islam.

Ketiga, internalisasi, proses penyerapan realitas subyektif dan realitas obyektif sebagai buah dari eksternalisasi dan obyektifikasi. Penyerapan ini mempengaruhi wilayah subyektif manusia. Pengaruh yang terus-menerus dalam relasi antara manusia dengan manusia, dan relasi antar manusia dengan lingkungannya dalam struktur sosial yang ada. Unsur positif pesantren banyak diserap oleh pesantren sendiri dan di komunitas luar pesantren.

Dinamika keilmuan pesantren dipahami Azyumardi Azra sebagai fungsi kelembagaan yang memiliki tiga peranan pokok. Pertama, transmisi ilmu pengetahuan Islam. Kedua, pemeliharaan tradisi Islam. Ketiga, pembinaan caloncalon ulama. Keilmuan pesantren lebih mengutamakan penanaman ilmu dari pada pengembangan ilmu. Hal ini terlihat pada tradisi pendidikan pesantren yang cenderung mengutamakan hafalan dalam transformasi keilmuan di pesantren. ${ }^{7}$

Tradisi pesantren yang memiliki keterkaitan dan keakraban dengan masyarakat lingkungan diharapkan dapat menciptakan suatu proses pendidikan tinggi yang melibatkan seluruh anggota masyarakat. Dengan demikian terciptalah masyarakat belajar, sehingga ada hubungan timbal balik antar keduanya. ${ }^{8}$ Di sini, masyarakat telah berperan serta dalam pendidikan di pesantren, sehingga pesantren dapat memahami masalah-masalah yang dihadapi masyarakat untuk mencarikan alternatif pemecahannya.

\section{B. Akar Kultural Pesantren; Fungsi, Tujuan dan Nilai}

Berbeda dengan lembaga pendidikan yang lain, yang pada umumnya menyatakan tujuan pendidikan dengan jelas, misalnya dirumuskan dalam anggaran dasar, maka pesantren, terutama pesantren-pesantren lama pada umumnya tidak merumuskan secara eksplisit dasar dan tujuan pendidikannya. Hal ini terbawa oleh sifat kesederhanaan pesantren yang sesuai dengan motivasi berdirinya, dimana kyainya mengajar dan santrinya belajar, atas dasar untuk ibadah dan tidak pernah di hubungkan dengan tujuan tertentu dalam lapangan penghidupan atau tingkat dan jabatan tertentu dalam hirarki sosial maupun ekonomi.

Karena itu, untuk mengetahui tujuan dari pada pendidikan yang diselenggarakan oleh pesantren, maka jalan yang harus ditempuh adalah dengan

\footnotetext{
7 Azyumardi Azra, Esai-Esai Intelektual Muslim Pendidikan Islam (Jakarta : Logos Wacana Ilmu, 1999), 89.

8 Ibid., 108.
} 
Evi Fatimatur Rusydiyah

pemahaman terhadap fungsi yang dilaksanakan dan dikembangkan oleh pesantren itu sendiri baik hubungannya dengan santri maupun dengan masyarakat sekitarnya. ${ }^{9}$ Hal demikian juga seperti yang pernah dilakukan oleh para wali di Jawa dalam merintis suatu lembaga pendidikan Islam, misalnya Syeih Maulana Malik Ibrahim yang dianggap sebagai bapak pendiri pondok pesantren, sunan Bonang atau juga sunan Giri. Yaitu mereka mendirikan pesantren bertujuan lembaga yang dipergunakan untuk menyebarkan agama dan tempat memperlajari agama Islam. ${ }^{10}$

Tujuan dan fungsi pesantren sebagai lembaga penyebaran agama Islam adalah, agar di tempat tersebut dan sekitar dapat dipengaruhi sedemikian rupa, sehingga yang sebelumnya tidak atau belum pernah menerima agama Islam dapat berubah menerimanya bahkan menjadi pemeluk-pemeluk agama Islam yang taat. Sedangkan pesantren sebagai tempat mempelajari agama Islam adalah, karena memang aktifitas yang pertama dan utama dari sebuah pesantren diperuntukkan mempelajari dan mendalami ilmu pengetahuan agama Islam. Dan fungsi-fungsi tersebut hampir mampu mempengaruhi pada kebudayaan sekitarnya, yaitu pemeluk Islam yang teguh bahkan banyak melahirkan ulama yang memiliki wawasan keislaman yang tangguh.

Dari pada transformasi sosial dan budaya yang dilakukan pesantren, pada proses berikutnya melahirkan dampak-dampak baru dan salah satunya reorientasi yang semakin kompleks dari seluruh perkembangan masyarakat. Bentuk reorientasi itu diantaranya, karena pesantren kemudian menjadi legitimasi sosial. Bagian dari reorientasi dari fungsi dan tujuan tersebut digambarkan oleh Abdurrahman Wahid ialah, diantaranya pesantren memiliki peran mengajarkan keagamaan, yaitu nilai dasar dan unsur-unsur ritual Islam. Dan pesantren sebagai lembaga sosial budaya, artinya fungsi dan perannya ditujukan pada pembentukan masyarakat yang ideal. Serta fungsi pesantren sebagai kekuatan sosial, politik dalam hal ini pesantren sebagai sumber atau tindakan politik, akan tetapi lebih diarahkan pada penciptaan kondisi moral yang akan selalu melakukan kontrol dalam kehidupan sosial politik. ${ }^{11}$

Apapun yang terjadi dalam dunia pesantren, termasuk sigmentasi fungsi dan tujuannya, sesuatu yang tidak dapat dipisahkan adalah, bahwa hubunganhubangan dan perubahan-perubahan yang terjadi dalam pesantren, karena adanya fenomena substansial dan mekanistik antara kyai, santri, metode dan kitab kuning sekaligus hubungan metodologisnya.

\footnotetext{
${ }_{9}^{9}$ Abdurrahman Wahid, Bunga Rampai Pesantren (Jakarta: Darma Bhakti, tt), 33.

${ }_{10}$ Marwan Saridjo, Sejarah Pondok Pesantren di Indonesia (Jakarta: Dharma Bhakti, 1980), 4.

11 Rahardjo, Pergulatan Dunia Pesantren, 8.

Jurnal Pendidikan Agama Islam (Journal of Islamic Education Studies)

Volume 5 Nomor 1 (2017)

ISSN(p) 2089-1946\& ISSN(e) 2527-4511

Hal. 26 - 43
} 
Sistem yang dikembangkan oleh pesantren adalah sebuah pranata yang muncul dari agama dan tradisi islam. Secara khusus Nurcholis Madjid, menjelaskan bahwa akar kultural dari sistem nilai yang dikembangkan oleh pesantren ialah ahlussunnah wal jama'ah.12 Di mana, jika dibahas lebih jauh akarakar kultural ini akan membentuk beberapa segmentasi pemikiran pesantren yang mengarah pada watak-watak ideologis pemahamannya, yang paling nampak adalah konteks intelektualitasnya terbentuk melalui "ideologi" pemikiran, misalnya dalam fiqh- lebih didominasi oleh ajaran-ajaran syafi'iyah, walaupun biasanya pesantren mengabsahkan madzhab arbain, begitu juga dalam pemikiran tauhid pesantren terpengaruh oleh pemikiran Abu Hasan al-Ash'ary dan juga al-Ghazali. ${ }^{13}$ Dari hal yang demikian pula, pola rumusan kurikulum serta kitab-kitab yang dipakai menggunakan legalitas ahlu sunnah wal jama'ah tersebut (madzhab Sunni).

Secara lokalistik faham sentralisasi pesantren yang mengarah pada pembentukan pemikiran yang terideologisasi tersebut, mempengaruhi pula pola sentralisasi sistem yang berkembang dalam pesantren. Dalam dunia pesantren legalitas tertinggi adalah dimiliki oleh Kyai, di mana Kyai disamping sebagai pemimpin "formal" dalam pesantren, juga termasuk figur yang mengarahkan orientasi kultural dan tradisi keilmuan dari tiap-tiap pesantren. Keunikan yang terjadi dalam pesantren demikian itu, menjadi bagian tradisi yang perlu dikembangkan, karena dari masing-masing memiliki efektifitas untuk melakukan mobilisasi kultural dan komponen-komponen pendidikannya. ${ }^{14}$

Akhirnya, Abdurrahman Wahid, menggarisbawahi bahwa pranata nilai yang berkembang dalam pesantren adalah berkaitan dengan visi untuk mencapai penerimaan disisi Allah dihari kelak menempati kedudukan terpenting, visi itu berkaitan dengan terminologi "keikhlasan", yang mengandung muatan nilai ketulusan dalam menerima, memberikan dan melakukan sesuatu diantara makhluk. Hal demikian itulah yang disebut dengan orientasi kearah kehidupan akherat (pandangan hidup ukhrawi). ${ }^{15}$ Bentuk lain dari pandangan hidup tersebut adalah kesediaan tulus menerima apa saja kadar yang diberikan kehidupan, walaupun dengan materi yang terbatas, akan tetapi yang terpenting adalah terpuaskan oleh kenikmatan rohaniah yang sangat eskatologi (keakheratan). Maka dari hal demikian pranata nilai ini memiliki makna positif, ialah kemampuan penerimaan perubahan-perubahan status dengan mudah serta flesibilitas santri dengan melakukan kemandirian hidup.

\footnotetext{
12 Nurcholis Madjid, Bilik-bilik Pesantren (Jakarta: Paramadina, 1997), 31.

13 Ibid., 32.

${ }^{14}$ Rahardjo, Editor Pergulatan Dunia Pesantren, 78.

15 Ibid., 45.
} 
Evi Fatimatur Rusydiyah

Maka jargon-jargon dan terminologi dalam pendidikan pesantren, terutama dalam mensuplimasi tata nilai ini adalah lebih menekankan sisi kehidupan yang mengedepankan unsur-unsur etika, moral dan spiritual daripada orientasi pembentukan pranata kecerdasan dan kepandaian, paling tidak visi yang ingin ditampilkan pesantren adalah adanya kehidupan yang seimbang dari dimensi kehidupan dunia dan akherat, walaupun menggunakan prioritaspieoritas tertentu.

\section{Peta Pemikiran Azyumardi Azra tentang Pesantren}

Azyumardi Azra merupakan tokoh pemikir yang tak pernah diam, Obsesinya yang besar untuk mengubah pemikiran Islam di Indonesia, telah dicurahkan melalui karya-karyanya baik dalam bentuk tulisan artikel yang dimuat diberbagai media masa maupun sejumlah buku yang telah diterbitkannya. Untuk itu, penulis akan menguraikan peta pemikiran Azyumardi Azra tentang pendidikan pesantren yang menjadi bagian yang tidak dapat dikesampingkan.

Menurut Azra, proses pendidikan dan pengajaran di pesantren sangat menekankan pada hafalan atau memorisasi. Hafalan sangat penting dalam segi transfer ilmu pengetahuan dan pemeliharaan tradisi Islam. Dalam tradisi keilmuan, tradisi hafalan sering dipandang sebagai lebih otoritatif dibandingkan dengan transmisi secara tertulis. Hal ini karena tradisi hafalan melibatkan transmisi secara langsung, melalui sema'an., untuk selanjutnya direkam, diserap dan direproduksikan. Dengan demikian, ilmu yang diterima betul-betul mendalam. ${ }^{16}$

Bagi masyarakat pesantren, ilmu hanya bisa diperoleh dengan jalan pengalihan, pewarisan, transmisi, bukan sesuatu yang diciptakan. Seperti dalam ta'lim-muta'alim, ilmu adalah sesuatu yang kamu ambil dari lisan rijal (guru), karena mereka telah menghafal bagian yag paling baik dari yang mereka dengar dan menyampaikan bagian yang paling baik dari yang mereka pernah hafal. ${ }^{17}$

Kekuatan yang ada dalam kedua metode tersebut, kemampuan akan menghafal sekian banyak pelajaran, ayat dan hadits di luar kepala. Tetapi perlu dipahami, di situ kemampuan atau potensi nalar tidak maksimal karena hanya doktrin harus menghafal sehingga banyak yang kurang memahami pelajaran yang dihafal. ${ }^{18}$ Kalau sistem pendidikan Barat, sistem hafalan tidak ditekankan

\footnotetext{
${ }^{16}$ Azra, Esai-Esai Intelektual Muslim dan Pendidikan Islam, 89.

${ }^{17}$ Affandi Mochtar, Membedah Diskursus Pendidikan Islam (Jakarta : Kalimah, 2001), 51.

18 Ali Hasan dan Mukti Ali, Kapita Selekta Pendidikan Agama Islam (Jakarta : Pedoman Ilmu Jaya, 2003), 98.
}

Jurnal Pendidikan Agama Islam (Journal of Islamic Education Studies)

Volume 5 Nomor 1 (2017)

ISSN(p) 2089-1946\& ISSN(e) 2527-4511

Hal. 28 - 43 
tetapi pemahaman yang merupakan aspek kognitif sangat diprioritaskan untuk menimbulkan pemahaman atau penafsiran baru yang lebih produktif.

Sementara mata pelajaran yang diajurkan di pesantren pada umumnya terdiri dari ilmu-ilmu alat di antaranya nahwu, shorof, bayan, ma'ani dan badi', ilmu tauhid, fiqh, mantiq, hadits, ushul fiqh dan tasawuf. Kitab-kitab standar yang digunakan pesantren dinamakan dengan kitab mu'tabarah yang masuk dalam kategori ahli sunnah wal jama'ah dnegan keterkaitan dengan salah satu madzab empat. Kitab-kitab tersebut dinamakan kitab kuning atau kutub qodimah. ${ }^{19}$

Kebanyakan kitab-kitab yang diajarkan di pesantren yaitu kitab-kitab yang pengarangnya berhaluan aliran suni. Berbeda dengan system pendidikan modern, yang disampaikan ilmu-ilmu lintas aliran. Sehingga didalam pesantren jarang ditemukan perbedaan pandangan antara guru dengan santri. Ilmu-ilmu ini(kitab kuning) hanya dipelajari sambil lalu, bahkan ada diantaranya yang tidak dipelajari kitabnya tetapi hanya dalam bentuk petuah atau nasehat kiai yang mengutip beberapa paragraf dalam kitab tertentu, kemudian para santri diperintahkan untuk mengamalkan dan meyakininya. Cara seperti ini biasanya berlaku untuk ilmu akhlaq dan kalam. ${ }^{20}$

Akan tetapi, biasanya pengajaran pertama di pesantren yang diterima murid membaca al-Qur'an dengan sedikit penekanan pada pemahaman, tetapi lebih pada intonasi dan ejaan yang benar bunyi dan hurufnya. Menurut Azra, semua murid yang ingin melakukan lebih dari sekedar mengintonasikan sebagian ayat suci yang diperlukan untuk sholat sehari-hari harus mempelajari bahasa Arab dengan serangkaian teks gramatikal. Azra menyebutkan banyak murid harus berjuang sangat keras atau menggunakan waktu bertahun-tahun sebelum mampu mengatasi kesulitan bahasa tersebut. Mereka yang mampu mengatasi kesulitan-kesulitan bahasa Arab, menurut Azra "dapat melangkah kepada pelajaran dan kajian syariat, biasanya disebut fiqh dan cabang ajaranajaran Islam lainnya”. ${ }^{21}$ Mereka belajar secara kontinyu tanpa mengenal batas waktu, yang ada bagaimana bisa menguasai ilmu. Jadi di sini mereka benar-benar mengamalkan pendidikan seumur hidup.

19 Kitab kuning merupakan salah satu ciri utama pengajaran di pesantren dan sebagai pembeda dengan tradisi keilmuan lembaga-lembaga pendidikan lainnya, seperti madrasah atau sekolah. Kitab-kitab kuning yang ditulis dalam bahasa Arab ada yang ditulis oleh para tokoh muslim Arab dan ada para pemikir muslim Indonesia. Baca Zainudin Fananie dan M. Thoyibi, Studi Asia Tenggara (Surakarta : Muhammadiyah University Press, 1999), 46.

${ }^{20} \mathrm{Al}$ Zastouw, Akar Pemikiran Pesantren, http://www.nu.or.id. Diakses pada 10 Juni 2017.

21 Azyumardi Azra, Surau, Pendidikan Islam Tradisional Dalam Transisi dan Modernisasi (Jakarta: Logos Wacana Ilmu, 2003), 99. 
Evi Fatimatur Rusydiyah

Dalam pengamatan Azra, mayoritas murid diajarkan pertama kali dasardasar Islam dan kemudian dibimbing kepada tingkah laku yang benar melalui syariat. Dia menyebutkan bahwa, buku-buku fiqh berbicara tentang rukun Islam yang lima yaitu syahadat, sholat, puasa, haji, dan zakat yang berada didalam bidang ibadah atau fiqh yang mengatur tingkah laku manusia terhadap Tuhan. ${ }^{22}$

Pesantren tidak mempelajari kitab-kitab yang dianggap gairu mu'tabar (tidak kwalified). Kalau dicermati, kitab-kitab yang dianggap mu'tabar oleh kalangan pesantren adalah kitab-kitab yang dikarang oleh para ulama yang tidak memiliki pemikiran radikal, seperti Syafi'i, Hanafi, Maliki dan Hambali (fiqh), Ghozali, Al Maturidi (tasawwuf), Ibn Rusyd, Buhkori, Muslim dan sebagainya. Pemikiran-pemikiran baru seperti yang ditawarkan Hassan alBanna, Sayyid Qutb dan sejenisnya yang cenderung radikal dan keras, tidak bisa diterima di pesantren, karena disamping dianggap tidak muktabar, pemikiranpemikiran tersebut juga dianggap tidak sesuai dengan tradisi dan nilai pesantren. ${ }^{23}$

Dalam waktu akhir-akhir ini, terdapat berbagai pendapat yang berbeda dalam madhab fiqh yang ada, sehingga muncul potensi tertentu bagi pengembangan dan penyesuaian. Seperti yang dikatakan Azra, "Kaum ulama tradisionalis kelihatannya lebih fleksibel dan longgar dalam merespon berbagai masalah fiqhiyyah, jika dibandingkan dengan ulama-ulama reformis dan modernis." ${ }^{24}$ Hal ini tidak terjadi terhadap masalah-masalah teologi. Teologi yang dipakai dalam pesantren masih menganut madhab Asy'ari dan Maturidi.

Sebelum abad 20 kaum tradisionalis indonesia tidak menggunakan hadis sahih Bukhari dan Muslim di lingkungan pesantren untuk mereka pelajari dan diajarkan para santri mereka. Sebaliknya, yang lebih populer dilingkungan pesantren adalah kumpulan "Hadits Empat Puluh", atau kitab-kitab kumpulan hadits ibadah dan akhlak.lebih jauh lagi Azra menambahkan : "Kebanyakan mereka menemukan hadits yang sudah diproses, yakni yang digunakan sebagai pendukung argumen fiqh, yang mereka pelajari sebagai subyek utama dalam pesantren."25 Dengan kata lain, mereka lebih baik mengikuti ulama-ulama terdahulu daripada mengambil pemahaman dan penafsiran sendiri berdasarkan al-Qur'an dan Hadits.

Dalam pandangan Azra, kaum tradisionalis cenderung menerima hadits secara relatif longgar dan tidak terlalu kritis atau tidak begitu mempersoalkan

\footnotetext{
22 Ibid., 103.

${ }^{23} \mathrm{Al}$ Zastouw, Akar Pemikiran Pesantren.

24 Azra, Islam Reformis, Dinamika Intelektual dan Gerakan (Jakarta : Raja Grafindo Persada, 1999), 70.

25 Ibid., 66.
}

Jurnal Pendidikan Agama Islam (Journal of Islamic Education Studies)

Volume 5 Nomor 1 (2017)

ISSN(p) 2089-1946\& ISSN(e) 2527-4511

Hal. 30 - 43 
tentang apakah hadits-hadits yang mereka terima merupakan hadits shahihatau hadits lemah, khususnya dari segi sanadnya. Mereka lebih mementingkan isi hadis tersebut, apalagi jika ada hadits yang mendorong kearah kebaikan dan amal sholeh. Hal ini berbeda dengan pandangan kaum modernis.

Kitab kuning yang diajarkan dalam pesantren sebenarnya memiliki sejarah yang amat panjang dan sekaligus membentuk suatu tradisi. menurut Azra Momentum pembentukan tradisi kitab kuning terjadi sejak awal abad ke19, ketika pesantren, surau, pondok mulai berkembang dan mapan sebagai institusi pendidikan Islam tradisional di berbagai daerah di Nusantara. Perkembangan dramatis institusi-institusi pendidikan Islam tradisional itu sendiri didorong oleh semangat perlawanan secara diam-diam terhadap kolonialisme Eropa, yaitu setelah perlawanan bersenjata yang dilancarkan masyarakat muslim dapat dilumpuhkan kaum kolonialis. Para ulama dan kaum santri ini kemudian memusatkan perhatian kepada pengembangan pendidikan Islam. Dari sini maka kebutuhan terhadap kitab kuning semakin meningkat. Menurutnya, kebutuhan terhadap kitab kuning dipenuhi dengan penyalinan secara manual sehingga banyak naskah-naskah yang tersimpan dan dipelihara secara individu-individu maupun dalam institusi. ${ }^{26}$

Dengan demikian kitab kuning mempunyai peran besar tidak hanya dalam transmisi ilmu pengetahuan Islam, bukan hanya di kalangan komunitas santri, tetapi juga di tengah masyarakat muslim Indonesia secara keseluruhan. Hal ini menjadikan kitab kuning merupakan ciri yang khas dalam pelajaran pesantren. Hampir semua kitab-kitab yang diajarkan di pesantren ditulis dalam huruf Arab, meski dalam bahasa Melayu atau Jawa.

Sejak abad ke-17 hingga akhir abad ke-19 para pelajar dari MelayuIndonesia menjadikan Haramain (Makkah dan Madinah) sebagai thalabul ilm mereka. Sehingga terjadi pertukaran kultural dan transmisi keagamaan dari Timur Tengah ke Indonesia. "Murid-murid Jalur dari sana (Haramain) telah terjadi kontak dengan sejumlah profesor dan rektor Al-Azhar."27

Hal tersebut menurut Azra, sangat penting tidak hanya dari sudut pandang keilmuan itu sendiri, tetapi juga dari perspektif sosial. Santri-santri yang menuntut ilmu di pesantren atau dari kiai tertentu di lingkungannya sendiri pada umumnya kurang memperoleh pengakuan sosial. Pengakuan sosial lebih tinggi malah akan mereka peroleh jika mereka telah menuntut ilmu di luar

Azra, Pendidikan Islam, $114 .^{26}$ Azyumardi Azra, Melacak Pengaruh dan Pergeseran Orientasi Tamatan Kairo : Sebuah 27 Pengantar Dalam Ma'na Abaza, Pendidikan Islam dan Pergeseran Orientasi, Studi Kasus Alumni Al-Azhar (Jakarta : Pustaka LP3ES, 1999), 87. 
Evi Fatimatur Rusydiyah

lingkungan daerah asalnya. Hal inilah yang mendorong santri melakukan perjalanan keilmuan ke pesantren lain untuk belajar dengan kiai-kiai lainnya.

\section{Pesantren dan Dinamika Pendidikan Islam}

Ditinjau dari segi historis, pesantren merupakan bentuk lembaga pribumi tertua di Indonesia. Pesantren sudah dikenal jauh sebelum Indonesia merdeka, bahkan sejak Islam masuk ke Indonesia, pesantren terus berkembang sesuai dengan perkembangan dunia pendidikan pada umumnya. Pondok pesantren berakar pada tradisi Islam sendiri dan sistem pendidikan model pondok pesantren adalah asli Indonesia. ${ }^{28}$

Model pendidikan pesantren yang berkembang di seluruh Indonesia mempunyai nama dan corak yang sangat bervariasi, di Jawa disebut pondok atau pesantren, di aceh di kenal rangkang dan di Sumatra Barat dikenal dengan nama Surau. Nama yang sekarang lazim diterima oleh umum adalah pondok pesantren. Pesantren sebagai komunitas dan sebagai lembaga pendidikan yang besar jumlahnya dan luas penyebarannya di berbagai plosok tanah air telah banyak memberikan peran dalam membentuk manusia Indonesia yang religius. Lembaga tersebut telah melahirkan banyak ke pemimpinan bangsa Indonesia di masa lalu, kini dan agaknya juga di masa datang. Lulusan pesantren telah memberikan partisipasi aktif dalam pembangunan bangsa.

Peran pesantren di masa lalu kelihatannya paling menonjol dalam hal menggerakkan, memimpin dan melakukan perjuangan dalam rangka mengusir penjajah. Di masa sekarang juga amat jelas ketika pemerintah mensosialisasikan programnya dengan melalui pemimpin-pemimpin pesantren. Pada masa-masa mendatang agaknya peran pesantren amat besar Misalnya, arus globalisasi dan industrialisasi telah menimbulkan depresi dan bimbanganya pemikiran serta suramnya prespektif masa depan maka pesantren amat dibutuhkan untuk menyeimbangakan akal dan hati. ${ }^{29}$

Di kalangan umat Islam sendiri nampaknya pesantren telah dianggap sebagai model institusi pendidikan yang memiliki keunggulan baik dari aspek tradisi keilmuannya yang merupakan salah satu tradisi agung maupun sisi transmisi dan internalisasi moralitas umat Islam. Malik Fajar menegaskan bahwa, dalam sejarah pertumbuhan dan perkembangan pendidikan Islam di Indonesia tidak dipungkiri bahwa pesantren telah menjadi semacam local genius. ${ }^{30}$ Hal ini menunjukkan bahwa peran pesantren telah merambah ke segala bidang bahkan telah menjadi bagian dari sistem pendidikan nasional kita, maka

\footnotetext{
28 DEPAG RI, Pondok Pesantren dan Madrasah Diniyah, 7.

${ }^{29}$ Tafsir, Ilmu Pendidikan dalam Prespektif Islam, 192.

${ }^{30}$ Fajar, Visi Pembaruan Pendidikan Islam, 126.

Jurnal Pendidikan Agama Islam (Journal of Islamic Education Studies)

Volume 5 Nomor 1 (2017)

ISSN(p) 2089-1946\& ISSN(e) 2527-4511

Hal. 32 - 43
} 
sangat keliru sekali ketika ada anggapan peran pesantren sangat kecil dan rendah dalam menyukseskan program pembangunan nasional.

Pesantren merupakan lembaga pendidikan Islam yang memiliki akar secara historis yang cukup kuat sehingga menduduki posisi relatif sentral dalam dunia keilmuan. Dalam masyarakatnya Pesantren sebagai sub kultur lahir dan berkembang seiring dengan perubahan-perubahan dalam masyarakat global, Asketisme ( faham Kesufian) yang digunakan pesantren sebagai pilihan ideal bagi masyarakat yang dilanda krisis kehidupan sehingga pesantren sebagai unit budaya yang terpisah dari perkembangan waktu, Menjadi bagian dari kehidupan masyarakat. Peranan seperti ini yang dikatakan Abdurrahman Wahid : "Sebagai ciri utama pesantren sebuah sub kultur." 31

Kehadiran pesantren dikatakan unik karena dua alasan yakni pertama, pesantren hadir untuk merespon terhadap situasi dan kondisi suatu masyarakat yang dihadapkan pada runtuhnya sendi-sendi moral atau bisa disebut perubahan sosial. Kedua, didirikannya pesantren adalah untuk menyebar luaskan ajaran universalitas Islam ke seluruh pelosok nusantara. ${ }^{32}$

Di samping itu, ada upaya untuk mendorong pesantren agar membina diri sebagai basis bagi upaya pengembangan pedesaan dan masyarakat yang di mulai pada awal-awal tahun tujuh puluhan yang pada saat ini telah berkembang menjadi usaha keras dan besar-besaran untuk transformasi social. Menurut Abdurrahman Wahid, peranan pesantren sebagai pelopor transformasi sosial seperti itu memerlukan pengujian mendalam dari segi kelayakan ide itu sendiri, di samping kemungkinan dampak perubahannya terhadap eksistensi pesantren..$^{33}$

Adanya gagasan untuk mengembangkan pesantren merupakan pengaruh program modernisasi pendidikan Islam. Program modernisasi tersebut berakar pada modernisasi pemikiran dan kelembagaan pesantren. ${ }^{34}$ Modernisasi pendidikan Islam tidak dapat dipisahkan dengan kebangkitan kaum muslimin di masa modern. Maka pemikiran dan kelembagan Islam termasuk pendidikan (pesantren) haruslah dimodernisasi yaitu diperbaharui sesuai dengan kerangka

31 Abdurrahman Wahid, Menggerakkan Tradisi, Esai-Esai Pesantren (Yogyakarta : LKIS Yogyakarta, 2001), 10.

32 Said Aqil Siradj (et.al), Pesantren Masa Depan, Wacana Pemberdayaan dan Transformasi Pesantren (Bandung : Pustaka Hidayah, 1999), 202.

33 Abdurrahman Wahid." Prospek Pesantren Sebagai Lembaga Pendidikan" Dalam Sonhaji Shaleh (terj); Dinamika Pesantren,Kumpuln Makalah Seminar Internasional, The Role of Pesantren in Education and Community Development in Indonesia" (Jakarta : P3M, 1988), 279.

${ }^{34}$ Lihat Zainal Alim, "Pergeseran Orientasi Kelembagaan Pesantren di Madura; Perspektif Kiai di Bangkalan" Jurnal Pendidikan Agama Islam (Journal of Islamic Education Studies) Vol.4 No.2 (2016). 
Evi Fatimatur Rusydiyah

modernitas. Dengan kata lain, mempertahankan pemikiran kelembagaan Islam tradisional akan memperpanjang nestapa ketertinggalan umat Islam dalam kemajuan dunia modern.

\section{E. Menyorot Dialektika Pesantren}

Akhir-akhir ini, ada kalangan yang menilai bahwa pendidikan Islam pesantren sebagai bidang kajian yang statis. Penilaian tersebut tidak sepenuhnya keliru meski tidak seluruhnya benar. Mereka dapat dinilai benar ketika pendidikan pesantren hanya dikaji pada tataran konseptual. Padahal, pendidikan pesantren tidak hanya fokus membahas masalah-masalah yang bersifat konsep, melainkan juga membahas masalah aplikasi dan implikasinya dari waktu ke waktu. Karena itu, pendidikan pesantren akan selalu mengalami dialektika; tidak diaplikasikan dalam konteks vakum, tetapi konteks yang selalu berubah dan mengalami dinamika dari waktu ke waktu.

Dengan dialektikanya, pesantren telah berjasa besar dalam menumbuhkan masyarakat swadaya dan swasembada. Penempatan pesantren sebagai pendidikan formal jalur sekolah yang dikembangkan pemerintah sebagai modernisasi pendidikan telah memudarkan ciri pesantren yang bebas, kreatif, berswadaya dan berswasembada. ${ }^{35}$ Kekhawatiran tersebut sangat beralasan karena adanya sentralisasi dan birokratisasi pendidikan nasional serta campur tangan yang dilakukan pemerintah.

"Perjalanan pendidikan Islam tradisional khususnya pesantren telah begitu panjang. Ketika arus globalisasi telah membawa perkembangan sosial kultur masyarakat yang semakin maju, maka tak heran ketika problem yang dialami pesantren sebagai pendidikan semakin kompleks."36

Sehingga Azra, meneliti tentang adanya permasalahan yang dihadapi sistem pemikiran dan pendidikan Islam yaitu pertama, berkenaan dengan situasi riil sistem pemikiran dan sistem pendidikan Islam, yaitu krisis konseptual. Krisis konseptual dimaksudkan tentang bagaimana persis dan sepatutnya secara epistimologi menjelaskan ilmu- ilmu empiris atau ilmu- ilmu alam dari kerangka epistimologi Islam.

Adanya dikotomi tersebut, Ismail Rozi Al-Faruqi pernah mengungkapkan bahwa faktor penyebab kelesuan intelektualisme Islam yaitu, proses penyempitan makna fikih serta status fakih yang jauh berbeda dengan pendiri

\footnotetext{
35 Abdul Munir Mulkhan, Nalar Spiritual Pendidikan, Solusi Problem Filosofis Pendidikan Islam (Yogyakarta : PT. Tiara Wacana Yogya, 2002), 180.

${ }^{36}$ Azra, Pendidikan Islam, 41.

Jurnal Pendidikan Agama Islam (Journal of Islamic Education Studies)

Volume 5 Nomor 1 (2017)

ISSN(p) 2089-1946\& ISSN(e) 2527-4511

Hal. 34 - 43
} 
madzab, pertentangan antara wahyu dan akal, keterpisahan kata dan perbuatan, serta sekulerisme dalam memandang budaya dan agama. ${ }^{37}$

Pemilahan yang terjadi di kalangan masyarakat muslim tidak hanya dalam lapangan keagamaan saja, tetapi juga dalam bidang lain termasuk sosial, ekonomi dan politik. Misalkan : wong cilik - abangan - kolot/modern dengan priyayi santri- kolot/modern, dan santri kolot dengan santri modern sehingga dalam masyarakat Islam sendiri ada pertentangan yang intens.

"Dalam konteks masyarakat muslim Indonesia juga terjadi pemilahan antara Islam tradisionalis dan Islam modernis. Di sini Islam modernis diwakili oleh Muhammadiyah, Persis, dan lain-lain; dengan Islam tradisionalis diwakili oleh NU dan sebagainya. Dikotomi tersebut secara struktural telah membawa perubahan-perubahan dalam pergerakan Islam selama beberapa dasa warsa akhir-akhir ini." 38

Permasalahan kedua, yaitu krisis lembaga. Krisis lembaga ini adanya dikotomisasi antara lembaga-lembaga pendidikan yang menekankan pada salah satu ilmu saja apakah itu ilmu agama atau ilmu umum. Menurut Azra, pengintegrasian antara ilmu umum dengan ilmu agama dalam upaya rekonstruksi ilmu harus melalui perumusan yang jelas, yaitu bagaimana ilmu-ilmu eksakta diajarkan dalam kerangka Islami. Bagaimana memberikan warna Islam terhadap ilmu-ilmu yang bersifat umum. ${ }^{39}$ Ilmu pengetahuan dan teknologi harus ditempatkan kembali ke dalam daerah pengawasan nilai agama, moral dan etika. Karena pada prinsipnya asal mula semua cabang ilmu pengetahuan adalah berpangkal pada ilmu agama. ${ }^{40}$ Pada masa Islam klasik, para intelektual Islam mampu mengembangkan dan mengislamkan ilmu pengetahuan modern. Semisal, ada nama ilmu pengetahuan dan teknologi modern Barat berasal dari bahasa Islam.

"Kecenderungan lembaga-lembaga pendidikan Islam lebih merupakan proses teaching, proses pengajaran ketimbang proses learning, proses pendidikan. Pengajaran hanya mengedepankan aspek kognitif, tetapi tidak mengisi aspek pembentukan pribadi dan watak." 41

37 Abdurrahman Mas'ud, Menggagas Format Pendidikan Nondikotomik, Humanisme Religius Sebagai Paradigma Pendidikan Islam (Yogyakarta : Gama Media, 2002), 5.

${ }^{38}$ Azra, Islam Reformis, 61.

${ }^{39}$ Azyumardi Azra, Rekonstruksi Kritis Ilmu dan Pendidikan Islam, dalam Abdul Munir Mulkhan (et.al), Rekonstruksi Pendidikan dan Tradisi Pesantren, Religiutas IPTEK, (Yogyakarta : Fak. Tarbiyah IAIN Sunan Kalijaga dan Pustaka Pelajar, 1998), 82.

40 Yasmadi, Modernisasi Pesantren : Kritikan Nurcholis Madjid Terhadap Pendidikan Islam Tradisional (Jakarta : Ciputat Press, 2002), 126.

${ }^{41}$ Azra, Rekonstruksi Kritis, 84. 
Penggunaan metode pendidikan Islam adalah bagaimana seorang pendidik dapat memahami hakikat metode dan relevansinya dengan tujuan utama pendidikan Islam, yaitu terbentuknya pribadi yang beriman yang senantiasa siap sedia mengabdi kepada Allah SWT dan bagaimana pendidik dapat mendorong anak didiknya menggunakan akal pikirannya dalam mempelajari kehidupannya dan alam sekitar. ${ }^{42}$

Untuk itu, pesantren semestinya membuka ruang baru dalam eksistensinya. Pesantren haruslebih inklusif terhadap realitas sosialnya. Dengan sikap terbuka pesantren ini, pesantren tetap bertahan sampai sekarang. Pesantren bukanlah komunitas agama yang ekslusif yang mengambil jarak dengan realitas perkembangan ilmu pengetahuan dan teknologi, dan hidup menyendiri tak mau bersinggungan dengan komunitas lain. Namun sikap terbuka tak lalu menghalalkan unsur negatif budaya lain, melainkan bersikap "oposan" terhadap budaya yang bertentangan dengan aqidah.

Pesantren sangat piawai berdialektika dengan tesis budaya yang saling bertentangan. Sehingga, lahir sintetis sebagai konstruksi sosial baru. Pesantren bisa menyatupadukan pendidikan agama dan pendidikan umum sekaligus, adalah contoh kongkrit. Betapa, pesantren adalah institusi sosial yang paling kreatif dan inovatif. Ini tak lepas dari falsafah sosial budaya pesantren: al-muhafadhu 'alal qadimis sholeh wal akhdu bil jadidil ashlah (memelihara tradisi lama yang baik dan mengambil tradisi baru yang lebih baik).

Berkat kreasi dan inovasi di dalamnnya, pesantren merupakan institusi sosial yang paling seksis. Banyak lembaga pendidikan yang menyerap sistem pendidikan pesantren yang dinilai teruji dan terbukti melahirkan manusia unggul: unggul moral, unggul intelektual dan unggul sosial. Keserbahadiran nilainilai agama yang memberi bobot atas sejumlah karya pendidikan, ekonomi dan budaya pesantren. Nilai-nilai agama ini pula yang mulai diujicoba untuk diterapkan oleh institusi pendidikan lain, guna mencegah tawuran pelajar, narkoba, seks bebas di kalangan pelajar, dan lain sebagainya.

\section{F. Pembaharuan Sistem Pendidikan Pesantren}

Gagasan pembaharuan pesantren di Indonesia diperkenalkan oleh kaum modernis dengan gagasan sekolah model Belanda pada tahun 1924. Pembaharuan pada waktu itu ditentang banyak oleh kaum konservatif (kyai) dikarenakan model sekolah-sekolah itu dapat memukul akar kekuasaan kyai yang terdalam. Namun semangat kaum modernis tidak dapat dibendung, mereka dengan hati-hati dalam programnya mendesak perlunya pengajaran mata

\footnotetext{
${ }^{42}$ Abdul Mujib Muhaimin, Pemikiran Pendidikan Islam : Kajian Filosofis dan Kerangka Dasar Operasionalisasinya (Bandung : Trigenda Karya, 1993), 230.
}

Jurnal Pendidikan Agama Islam (Journal of Islamic Education Studies)

Volume 5 Nomor 1 (2017)

ISSN(p) 2089-1946\& ISSN(e) 2527-4511

Hal. 36 - 43 
pelajaran modern dengan cara- cara modern, mereka memasukkan Islam sebagai suatu mata pelajaran modern dan membuatnya sebagai bagian yang yang tak terpisahkan dari kurikulum sekolah. ${ }^{43}$

“Pesantren Mambaul Ulum di Surakarta mengambil tempat paling depan dalam merambah bentuk respon pesantren terhadap Ekspansi pendidikan Belanda dan pendidikan modern Islam. Peantren Mambaul Ulum yang didirikan Susuhunan Pakubuwono ini pada tahun 1906 merupakan perintis dari penerimaan beberapa mata pelajaran Umum dalam pendidikan pesantren. Menurut laporan inspeksi pendidikan belanda pada tahun tersebut, pesantren mambaul ulum telah memasukkan mata pelajaran membaca (tulisan latin), Aljbar, dan berhitung kedalan kurikukulmnya. Respon yang sama tetapi dalam nuansa yang sedikit berbeda terlihat dalam pengalaman Pondok Modern Gontor. Berpijak pada basis system dan kelembagaan pesantren, pada 1926 berdirilah Pondok Modern Gontor. Pondok ini selain memasukkan sejumlah mata pelajaran Umum kedalam kurikulumnya, juga mendorong para santrinya untuk memelajari Bahasa Inggris (selain bahasa Arab) dan melaksanakan sejumlah kegiatan ekstra kurikulker seperti olahraga, kesenian dansebagainya. ${ }^{44}$

Modernisasi di manapun telah mengubah berbagai tatanan dan lembaga tradisional (pesantren). Salah satu di antaranya adalah semakin pudarnya fungsi lembaga Islam. Pudarnya fungsi lembaga keagamaan tradisional dalam kehidupan modern merupakan penjelas perubahan posisi sosial, ekonomi dan politik elite Muslim yang dibangun di atas kekuasaan dan legitimasi keagamaannya. "Pemikiran Islam kontemporer merupakan upaya elite muslim memperoleh legitimasi agama atas posisi sosial, ekonomi dan politiknya dalam lembaga sekuler." 45

Munculnya kesadaran di kalangan pesantren dalam mengambil langkahlangkah pembaharuan untuk menjawab tantangan dan kebutuhan transformasi sosial. Misalnya timbul pembaharuan kurikulum dan kelembagaan pesantren yang berorientasi pada kekinian sebagai respon dari modernitas. Bagi Azyumardi Azra perlu dikaji ulang gagasan tersebut, sebab bukan tidak mungkin orientasi semacam itu akan menimbulkan implikasi negatif terhadap eksistensi dan fungsi pokok pesantren.

"Pesantren harus menumbuhkan apresiasi yang sepatutnya terhadap semua perkembangan yang terjadi di masa kini dan mendatang, sehingga dapat memproduksi ulama yang berwawasan luas." 46

43 Clifford Geertz, Abangan, Santri, Priyayi dalam Masyarakat Jawa (Jakarta : Dunia Pustaka Jaya, 1983), 250.

${ }^{44}$ Azra, Pendidikan Islam, 102.

45 Abdul Munir Mulkan, Paradigma Intelektual Muslim, Pengantar Filsafat Pendidikan Islam dan Dakwah (Yogyakarta :SIPRESS, 1993), 127.

${ }^{46}$ Azra, Pendidikan Islam, 51. 
Walaupun pesantren sudah banyak yang mengadakan perubahanperubahan mendasar, namun Zamaksyari Dhofier menilai perubahan tersebut masih sangat terbatas. Menurutnya ada dua alasan utama yang menyebabkan, yaitu pertama, para kyai masih mempertahankan dasar-dasar tujuan pendidikan pesantren, yaitu bahwa pendidikan pada dasarnya ditujukkan untuk mempertahankan dan menyebarkan Islam. Kedua, mereka belum memiliki staf sesuai dengan kebutuhan pembaharuan untuk mengajarkan cabang-cabang pengetahuan umum. ${ }^{47}$

Hasyim Muzadi, menambahkan dalam menghadapi realitas kekinian, kita tidak harus skeptis dalam menerapkan metodologi dan tidak usah mengacakacak modernitas, atas nama keharusan perubahan itu sendiri. Tradisi menjadikan agama bercokol dalam masyarakat harus lebih kreatif dan dinamis sebab mampu bersenyawa dengan aneka ragam unsur kebudayaan. Sedangkan modernitas tetap perlu guna terobosan-terobosan baru di bidang pemikiran atau IPTEK tidak sampai tersandung. Maka harus ada kesesuaian antara penguasaan materi agama dengan kemampuan nalar, sehingga ada sinergi antar keduanya, jangan sampai doktrin agama dimaknai secara sempit.48

Apa yang diungkapkan Hazyim Muzyadi mirip dengan apa yang dimaksud oleh Muhammad Abduh mengenai tujuan Pendidikan dalam arti luas yaitu " Mencakup aspek akal (kognitif) Dan Aspek spiritual (Afektif)". Disini Abduh menginginkan terbentuknya pribadi yang mempunyai Struktur jiwa yang seimbang, yang tidak hanya menekankan pekembangan akal tetapi juga perkembangan spiritual. ${ }^{49}$

"Dinamika keilmuan pesantren merupakan fungsi kelembagaan yang memiliki tiga peranan pokok. Pertama, transmisi ilmu pengetahuan Islam. Kedua, pemeliharaan tradisi Islam. Ketiga, pembinaan calon-calon ulama. Keilmuan pesantren lebih mengutamakan penanaman ilmu dari pada pengembangan ilmu. Hal ini terlihat pada tradisi pendidikan pesantren yang cenderung mengutamakan hafalan dalam transformasi keilmuan di pesantren." ${ }^{50}$

Tradisi pesantren yang memiliki keterkaitan dan keakraban dengan masyarakat lingkungan diharapkan dapat menciptakan suatu proses pendidikan tinggi yang melibatkan seluruh anggota masyarakat. Dengan demikian

47 Zamakhsyari Dhofier, Tradisi Pesantren, Studi Tentang Pandangan Hidup Kyai (Jakarta : LP3ES 1994), 39.

48 M. Hasyim Muzadi, Nahdlatul Ulama di Tengah Agenda Persoalan Bangsa (Jakarta : Logos, 1999), 121.

49 Abdul Kholik (at.al), Pemikiran Pendidikan Islam, Kajian Tokoh Klasik dan Kontemporer (Yogyakarta : Fak. Tarbiyah IAIN Walisongo Semarang Dan Pustaka Pelajar,1999), 189.

${ }^{50}$ Azra, Esai-Esai Intelektual Muslim Pendidikan Islam, 89.

Jurnal Pendidikan Agama Islam (Journal of Islamic Education Studies)

Volume 5 Nomor 1 (2017)

ISSN(p) 2089-1946\& ISSN(e) 2527-4511

Hal. 38 - 43 
terciptalah masyarakat belajar, sehingga ada hubungan timbal balik antar keduanya. Di sini, masyarakat telah berperan serta dalam pendidikan di pesantren, sehingga pesantren dapat memahami masalah-masalah yang dihadapi masyarakat untuk mencarikan alternatif pemecahannya. ${ }^{51}$

Pesantren telah berjasa besar dalam menumbuhkan masyarakat swadaya dan swasembada. Penempatan pesantren sebagai pendidikan formal jalur sekolah yang dikembangkan pemerintah sebagai modernisasi pendidikan telah memudarkan ciri pesantren yang bebas, kreatif, berswadaya dan berswasembada. ${ }^{52}$ Kekhawatiran tersebut sangat beralasan karena adanya sentralisasi dan birokratisasi pendidikan nasional serta campur tangan yang dilakukan pemerintah.

Perjalanan pendidikan Islam tradisional khususnya pesantren telah begitu panjang. Ketika arus globalisasi telah membawa perkembangan sosial kultur masyarakat yang semakin maju, maka tak heran ketika problem yang dialami pesantren sebagai pendidikan semakin kompleks, sehingga Azra meneliti tentang adanya permasalahan yang dihadapi sistem pemikiran dan pendidikan Islam yaitu pertama, berkenaan dengan situasi riil sistem pemikiran dan sistem pendidikan Islam, yaitu krisis konseptual. Krisis konseptual dimaksudkan tentang bagaimana persis dan sepatutnya secara epistimologi menjelaskan ilmuilmu empiris atau ilmu- ilmu alam dari kerangka epistimologi Islam.53

Adanya dikotomi tersebut, Ismail Rozi Al-Faruqi pernah mengungkapkan bahwa faktor penyebab kelesuan intelektualisme Islam yaitu, proses penyempitan makna fikih serta status fakih yang jauh berbeda dengan pendiri madzab, pertentangan antara wahyu dan akal, keterpisahan kata dan perbuatan, serta sekulerisme dalam memandang budaya dan agama.54

Dalam konteks masyarakat muslim Indonesia juga terjadi pemilahan antara Islam tradisionalis dan Islam modernis. Di sini Islam modernis diwakili oleh Muhammadiyah, Persis, dan lain-lain; dengan Islam tradisionalis diwakili oleh NU dan sebagainya. "Dikotomi tersebut secara struktural telah membawa perubahan-perubahan dalam pergerakan Islam selama beberapa dasa warsa akhir-akhir ini." 55

51 Ibid, 108.

52 Abdul Munir Mulkhan, Nalar Spiritual Pendidikan, Solusi Problem Filosofis Pendidikan Islam (Yogyakarta : Tiara Wacana Yogya, 2002), 180.

53 Azra, Pendidikan Islam, 41.

54 Mas'ud, Menggagas Format Pendidikan Nondikotomik, 5.

55 Azra, Islam Reformis, 61. 
Evi Fatimatur Rusydiyah

Permasalahan kedua, yaitu krisis lembaga. Krisis lembaga ini adanya dikotomisasi antara lembaga-lembaga pendidikan yang menekankan pada salah satu ilmu saja apakah itu ilmu agama atau ilmu umum. Menurut Azyumardi Azra,

"Pengintegrasian antara ilmu umum dengan ilmu agama dalam upaya rekonstruksi ilmu harus melalui perumusan yang jelas, yaitu bagaimana ilmuilmu eksakta diajarkan dalam kerangka Islami. Bagaimana memberikan warna Islam terhadap ilmu-ilmu yang bersifat umum." 56

Dalam salah satu redaksi, Azra melanjutkan :

"Bagaimana menempatkan kembali ilmu pengetahuan dan teknologi ke dalam daerah pengawasan nilai agama, moral dan etika. Karena pada prinsipnya asal mula semua cabang ilmu pengetahuan adalah berpangkal pada ilmu agama. Pada masa Islam klasik, para intelektual Islam mampu mengembangkan dan mengislamkan ilmu pengetahuan modern. Misalkan ada nama ilmu pengetahuan dan teknologi modern Barat berasal dari bahasa Islam.." 57

Para intelektual muslim pada masa Islam klasik hanya lahir dari satu lembaga yaitu madrasah atau pesantren tanpa ada pemilahan madrasah yang umum atau agama.

Persoalan ketiga yaitu krisis metodologi. Kecenderungan lembagalembaga pendidikan Islam lebih merupakan proses teaching, proses pengajaran ketimbang proses learning, proses pendidikan. "Pengajaran hanya mengedepankan aspek kognitif, tetapi tidak mengisi aspek pembentukan pribadi dan watak."58 Penggunaan metode pendidikan Islam adalah bagaimana seorang pendidik dapat memahami hakikat metode dan relevansinya dengan tujuan utama pendidikan Islam, yaitu terbentuknya pribadi yang beriman yang senantiasa siap sedia mengabdi kepada Allah SWT dan bagaimana pendidik dapat mendorong anak didiknya menggunakan akal pikirannya dalam mempelajari kehidupannya dan alam sekitar. ${ }^{59}$

Arus globalisasi telah mempengaruhi segalanya dan merupakan tantangan tersendiri yang harus dihadapi oleh pesantren yaitu bagaimana merespon segala perubahan yang terjadi di dunia luarnya tanpa merubah dan meninggalkan identitas pesantren itu sendiri. Sehingga pesantren tetap eksis di tengah-tengah masyarakat modern.

\footnotetext{
${ }^{56}$ Azyumardi Azra, Rekonstruksi Kritis Ilmu dan Pendidikan Islam, dalam Abdul Munir Mulkhan (et.al), Rekonstruksi Pendidikan dan Tradisi Pesantren, Religiutas IPTEK, (Yogyakarta : Fak. Tarbiyah IAIN Sunan Kalijaga dan Pustaka Pelajar, 1998), 82.

57 Yasmadi, Modernisasi Pesantren, 126.

${ }^{58}$ Azra, Rekonstruksi Kritis Ilmu dan Pendidikan Islam, 84.

${ }^{59}$ Muhaimin \& Abdul Mujib, Pemikiran Pendidikan Islam : Kajian Filosofis dan Kerangka Dasar Operasionalisasinya (Bandung : Trigenda Karya, 1993), 230.
}

Jurnal Pendidikan Agama Islam (Journal of Islamic Education Studies)

Volume 5 Nomor 1 (2017)

ISSN(p) 2089-1946\& ISSN(e) 2527-4511

Hal. 40 - 43 


\section{G. Kesimpulan}

Bagian ini adalah simpulan penulis atas penelitian pustaka ini. Penulis dapat menarik benang merah bahwa Azyumardi Azra mengemukakan bahwa pesantren sebagai lembaga pendidikan indigenous Jawa, tradisi keilmuannya dalam banyak hal memiliki kesamaan dengan lembaga-lembaga pendidikan Islam tradisional di daerah dunia Islam lainnya. Kesamaan tersebut menurutnya bukan hanya pada tingkat kelembagaan dan keterkaitannya dengan lingkungan sosialnya, tetapi juga pada watak dan karakter keilmuannya. Hal itu menjadi keunikan tersendiri pesantren sebagai lembaga pendidikan Islam.

Menurut Azra, pesantren saat ini terus berbenah dan mempersolek diri, dan sisi lain banyak pihak mengadopsi unsur positif dalam diri pesantren. Pesantren menumbuhkan apresiasi yang sepatutnya terhadap semua perkembangan yang terjadi di masa kini dan mendatang. Proses take and give secara sosiologis dan antropologis ini, sejatinya merupakan konstruksi social yang ada di Pesantren. Dan dinamika pendidikan pesantren dipahami Azra sebagai fungsi kelembagaan yang memiliki tiga peranan pokok. Pertama, transmisi ilmu pengetahuan Islam. Kedua, pemeliharaan tradisi Islam. Ketiga, pembinaan calon-calon ulama.

\section{H. Referensi}

Alim, Zainal. "Pergeseran Orientasi Kelembagaan Pesantren di Madura; Perspektif Kiai di Bangkalan". Jurnal Pendidikan Agama Islam (Journal of Islamic Education Studies) Vol.4 No.2 (2016).

Azra, Ayumardi. Pendidikan Islam,Tradisi dan Modernisasi Menuju Melinium Baru. Jakarta: Logos Wacana Ilmu, 2000.

. Esai-Esai Intelektual Muslim Pendidikan Islam. Jakarta : Logos Wacana Ilmu, 1999.

. Islam di Tengah Arus Transisi. Jakarta : Kompas, 2000.

. Islam Reformis, Dinamika Intelektual dan Gerakan. Jakarta : Raja Grafindo Persada, 1999.

Jaringan Ulama Timur Tengah dan Kepulauan Nusantara Abad XVII dan XVIII, Melacak Akar-Akar Pembeharuan Pemikiran Islam di Indonesia. Bandung : Mizan, 1995.

. Melacak Pengaruh dan Pergeseran Orientasi Tamatan Kairo : Sebuah Pengantar Dalam Ma'na Abaza, Pendidikan Islam dan Pergeseran Orientasi, Studi Kasus Alumni Al-Azhar. Jakarta : Pustaka LP3ES, 1999.

. Surau, Pendidikan Islam Tradisional Dalam Transisi Dan Modernisasi. Jakarta: Logos Wacana Ilmu, 2003. 
Evi Fatimatur Rusydiyah

Depag RI. Pondok Pesantren dan Madrasah Diniyah; Pertumbuhan dan Perkembangannya. Jakarta: Direktorat Jenderal Kelembagaan Agama Islam, 2003.

Dhofier, Zamakhsyari Tradisi Pesantren, Studi Tentang Pandangan Hidup Kyai. Jakarta : LP3ES 1994.

Fadjar, Malik Visi Pembaruan Pendidikan Islam. Jakarta : Lembaga Pengembangan Pendidikan dan Penyusunan Naskah Indonesia / LP3NI, 1998.

Fananie, Zainudin., Thoyibi, M. Studi Asia Tenggara. Surakarta : Muhammadiyah University Press, 1999.

Geertz, Clifford Abangan, Santri, Priyayi dalam Masyarakat Jawa. Jakarta : Dunia Pustaka Jaya, 1983.

Hasan, Ali., dan Ali, Mukti. Kapita Selekta Pendidikan Agama Islam. Jakarta : Pedoman Ilmu Jaya, 2003.

Kholik, Abdul. Pemikiran Pendidikan Islam, Kajian Tokoh Klasik dan Kontemporer. Yogyakarta : Fak. Tarbiyah IAIN Walisongo Semarang Dan Pustaka Pelajar, 1999.

Madjid, Nurcholis. Bilik-Bilik Pesantren. Jakarta: Paramadina, 1997.

Mas'ud, Abdurrahman. Menggagas Format Pendidikan Nondikotomik; Humanisme Religius Sebagai Paradigma Pendidikan Islam. Yogyakarta : Gama Media, 2002.

Mochtar, Affandi. Membedah Diskursus Pendidikan Islam. Jakarta : Kalimah, 2001.

Muhaimin, Abdul Mujib. Pemikiran Pendidikan Islam : Kajian Filosofis dan Kerangka Dasar Operasionalisasinya. Bandung : Trigenda Karya, 1993.

Mulkan, Abdul Munir. Paradigma Intelektual Muslim, Pengantar Filsafat Pendidikan Islam dan Dakwah. Yogyakarta : SIPRESS, 1993.

Nalar Spiritual Pendidikan, Solusi Problem Filosofis Pendidikan Islam. Yogyakarta : Tiara Wacana Yogya, 2002.

Rekonstruksi Pendidikan dan Tradisi Pesantren, Religiutas IPTEK Yogyakarta : Fak. Tarbiyah IAIN Sunan Kalijaga dan Pustaka Pelajar, 1998.

Muzadi, Hasyim Nahdlatul Ulama, di Tengah Agenda Persoalan Bangsa. Jakarta : Logos, 1999.

Rahardjo, M. Dawam. Pergulatan Dunia Pesantren. Jakarta: LP3ES, 1985.

Saridjo, Marwan. Sejarah Pondok Pesantren di Indonesia. Jakarta: Dharma Bhakti, 1982. 
Shaleh, Sonhaji. Dinamika Pesantren; Kumpulan Makalah Seminar Internasional, The Role of Pesantren in Education and Community Development in Indonesia (Jakarta : P3M, 1988.

Siradj, Said Aqil. Pesantren Masa Depan; Wacana Pemberdayaan dan Transformasi Pesantren. Bandung : Pustaka Hidayah, 1999.

Tafsir, Ahmad Ilmu Pendidikan Dalam Perspektif Islam. Bandung : Remaja Rosdakarya, 2001.

Wahid, Abdurrahman. Bunga Rampai Pesantren. Jakarta: Darma Bhakti, tt.

LkiS, 2001. Menggerakkan Tradisi, Esai-Esai Pesantren. Yogyakarta :

Yasmadi. Modernisasi Pesantren : Kritikan Nurcholis Madjid Terhadap Pendidikan Islam Tradisional. Jakarta : Ciputat Press, 2002.

Al Zastouw, Akar Pemikiran Pesantren, http://www.nu.or.id. 